\title{
Why Intersemiotics Isn't Enough? Remarks on Intersemiotic and Intermedial Studies
}

This paper has been classified as theoretical. This fact makes me a bit uneasy, since I do not regard myself as a theorist. In this respect, I share Jonathan Culler's ambivalence as to the vast concern for theory in today's humanities (Culler 1997: 15). Being a literary scholar with a musicological background, I have been focusing, instead, on specific analytical problems concerning relationships between poetry and music. However, while dealing with these problems, I have not been able to exclude numerous other phenomena usually considered insignificant for the art forms mentioned: such as visuality, spatiality or materiality. Thus, this article will demonstrate my own search for adequate tools to explore artistic projects of a transgressive nature, commonly referred to as borderline phenomena.

At the outset, let me mention an event which occurred while I was working on this paper, while using the on-line dictionary thesaurus.com to check vocabulary. Inserting the term CRATILISM (which designates an ancient theory, as opposed to the structuralist assertion of the arbitrary nature of linguistic signs), I got the following answer: "No thesaurus results. Did you mean CRETINISM?"

This may seem quite funny and I had a really good laugh, until I discovered the undeniable logic at the roots of the operation performed by the search engine. Not having found the requested word, the software offered the most likely word, instead, on the basis of the image of the word. In fact, both these words are really close to each other as to their sign content: that is, certain graphic signs in a certain order. These two words are only differentiated by two graphic signs: 
By the way, how would we react seeing an incomplete word like this: CR TI ISM? Maybe CRITICISM? Well, if we do not know the context, we are not better than our computer.

As a matter of fact, the computer did well, according to the principle of probability, which is a numerical - not a linguistic - order, however. This is the fact corrupting our expectations as to potential results. Here, we get to the heart of the matter. We operate within a great number of overlapping semiotic systems that constitute the basic conditions for communication, for which the linguistic system appears as paradigmatic. As social beings, we have learned to decode and comprehend signs, not only within firstorder semiotic systems (i.e., natural language), but also second-order systems, based on culturally established conventions (i.e., literature). Consequently, the interpretive energy may be successfully transferred beyond particular semiotic systems toward intersemiotic translation, even called transposition (Clüver 1989: 59) ${ }^{1}$ or transformation (Lund 2002: 21).

The topic of this volume, Intersemiotic Translation, seems to be based on a positive assumption about the phenomenon and its relevance for numerous artistic endeavours. However, the title of my paper suggests this might not be a universal perspective for examining complex genres of modern art and communication. It alludes to William P. Germano's article, "Why Interdisciplinarity Isn't Enough?" (1997: 327-334) published in the volume, The Practice of Cultural Analysis: Exposing Interdisciplinary Interpretation (Bal, Gonzales 1997). That text aimed at separating the notions of cultural studies and interdisciplinary studies, arguing that they differ as to the subject of their study, focusing on - respectively - the variety of contemporary culture and the $19^{\text {th }}$ century's concept of fine arts. My presentation will have a similar standpoint when it comes to intersemiotic and intermedial studies, since I regard the latter as a considerable extension of the former.

Roman Jakobson is credited with extending the notion of translation beyond the area of linguistics. The assumption that meaning can be transferred between different sign systems brought about a breakthrough in comparative studies that expanded beyond the traditional academic fields, stemming from the principles of aesthetics. As a matter of fact, semiotics served as a common basis for dealing with different art forms treating them as the outcome of the same signifying power governed by universal rules.

${ }^{1}$ Clüver adopted this term from Gisbert Kranz' typology of relationships between picture and poem in Bildgedicht (Kranz 1981: 29). 
Claus Clüver was among those who adapted his interdisciplinary oriented scholarship to the emerging theoretical endeavours - from intersemiotic via interart to intermedial studies. Nevertheless, as approving of the idea of intersemiotic translation as he was, he pointed out some of its limitations. Firstly, he noted a privileged position of the source text (or "original") compared with the target text, which was to be examined as to its adequacy, not for its own sake: "To be considered successful, the target text is expected to offer equivalents for all aspects and features of the source text" (Clüver 1989: 59). On the other hand, the notion of translation - or transposition - actually involves a single text, whether the other is absent, implicit or merely assumed. Is that not an echo of the ancient platonic cave where the real thing, ideas, cannot be rendered in its entirety?

Clüver also raised the issue of the mode of interpretation, depending on whether a text is approached as an intersemiotic transposition or without any hints about the preexisting text (Clüver 1989: 56). Moreover, he noticed that some art forms were more likely to be transformed, i.e., visual to verbal, and not in opposite direction - quite an astonishing lack of symmetry. Finally, he believed that intersemiotic transposition could not cover all possible affinities between visual and verbal texts, pointing to genres such as Bildgedicht or ekphrasis, which encompass a wider range of relationships between the texts concerned, such as "an interpretation, a meditation, a commentary, a critique, an imitation, a counter creation" (Clüver 1989: 69). ${ }^{2}$ In this light, intersemiotic translation is only one of the possible intersemiotic relationships. Needless to say, various genres and art forms encompass two or more semiotic systems at the same time, where intersemiotic relations can be found and scrutinized. In such cases, the mode of translation, transposition, or transformation appears far too narrow, as there is no transfer but, instead, there are coexistence, cooperation and mutual influences that produce new meanings.

What Clüver observed in the intersemiotic analyses was the predominant focus on the hermeneutic interpretation at the expense of other features of the art works:

Less has been said about correspondences between signifiers as such, and very little indeed about the ways in which the textures of visual marks and of sounds and graphic marks, the material aspects of the texts, may be seen to relate to each other. It is at that level that the texts constructed and interpreted, and the verbalisation of these interpretations by individual readers, will vary most, and it is here that we are most aware of the inadequacy of words to render visual data (and perhaps also of the violence done to the visual text in the process) (Clüver 1989: 83).

${ }^{2}$ Note well that ekphrasis can recreate a non-existing visual object, which is the case with the "Ode on a Grecian Urn" by John Keats (Clüver 1989: 77). 
Following Clüver's re-orientation toward a broader analytical perspective, as well as from my own scholarly experience, I regard intersemiotic studies as a more or less historical stage in the practice of comparing, confronting and merging arts and media, which has its limitations, especially as to the widely understood materiality of signs. The mentioned neglected properties of texts would become essential for intermedial studies, which have been growing since the $1990^{\mathrm{s}}$ along with interart studies, but quite recently even replacing the latter. Moreover, they aspire, and not without strong foundation, to become "the discipline underlying any conceivable study of cultural artifacts" (Arvidson et al. 2007b: 14), since intermediality is regarded as a precondition of art and communication in general.

Going through the variety of definitions and approaches within this field falls beyond the scope of this paper. Let me just name some that turned out to be especially long-lived and applicable. Clüver's distinction of texts as medial constructs in multimedia, mixed-media and intermedia texts, as to the degree of integration of the media involved is still valid (Clüver 2007: 25), as well as Hans Lund's useful division of relationships between media: combination, integration and transformation (Lund 2002: 20). Nevertheless, today's intermedial studies focus rather on W.J.T. Mitchell's assertion that all media are mixed-media (1994: 5). Consequently, it is not the nature of particular media but their acting and functions within artifacts that are subject of scrutiny. ${ }^{3}$ Recent research in the theory of intermediality, held predominantly in Scandinavia, with Lars Elleström as one of the leading scholars in the field, brought about new categories of intermedial relationships, stressing the notion of border - not in order to separate the areas within borders, but to investigate the borders themselves, where all intermedial actions usually take place. Two influential volumes mark the state of the art in the field of intermedial studies: Changing Borders: Contemporary Positions in Intermediality (Arvisdon et al. 2007a) and Media Borders: Multimodality and Intermediality (Elleström 2010a).

The proposed framework for intermedial investigations does not, in any way, oppose research in semiotic (and intersemiotic) qualities of art works, which are regarded as only one of the aspects of intermedial relations. Thus, Elleström avoids defining the medium but, instead, names four so-called modalities of media which are the most basic categories

${ }^{3}$ Let me just mention the $10^{\text {th }}$ international conference of the Nordic Society for Intermedial Studies (NorSIS) "Media Acts" held at the Department of Art and Media Studies at NTNU in Trondheim 2011. 
of their possible features: material modality (the way of mediating signs), sensorial modality (the way of perception and involvement of the senses), spatiotemporal modality (concerning the cognitive conditions which tend to fix perception data in space and time), and - last but not least - semiotic modality, connected to meaning (Elleström 2010b: 17-24). This requires semiotic qualities to be based and, thus, be dependent on material, sensorial and spatiotemporal ones.

I am not going to discuss those categories in more detail, since they have been thoroughly elaborated on, in the books mentioned. I would prefer to present my own search for an appropriate perspective for coping with Swedish neo-avant-garde art forms flourishing in the $1950^{\text {s }}$ and $1960^{\text {s, }}$ invalidating the traditional aesthetic principles of art and the established rules for artistic communication. Let me again refer to the episode I mentioned at the beginning, concerning failing communication between the user and the search engine (cratilism versus cretinism). As long as we operate within established sign systems, we are able to decode, interpret and - by incomplete message - even make assumptions about the function and meaning of signs. However, without any contextual framework, when the familiar codes and conventions seem not to work, we are confused, disoriented or - alert to solving the problem by seeking new strategies of comprehension.

Swedish concrete poetry emerged in the early 1950s as a phenomenon coinciding with other concretist endeavours in Brazil, Switzerland, and Germany, but fully independent and based on other premises. Unlike the Swiss or the Brazilian, it did not aim at reducing language material and achieving the effect of verbal-visual purity, but developed the socalled dirty concrete, a term coined by Marjorie Perloff (1991: 114; see also Olsson 2005: 13) describing artifacts derived from ecstatic production of texts, according to the method of treating "language as concrete material", launched by Swedish neo-avant-garde artist Öyvind Fahlström in his Manifesto of Concrete Poetry (1968: 75).

The language of Fahlström's poems (see Fig. 1) is defragmented. Its segments are combined according to serial patterns and permutations. More recognizable units as citations, phrases, fragments of conversations and verbal "ready-mades" are arranged according to the logic of collage, mimetically reflecting the polyphonic world. Graphically, the linear language order becomes disintegrated and changes into spatial organization - vertical (in the form of independent text blocks) or spread across the page, which - as Clüver put it - "invites or even obliges the reader to pursue different paths through the text" (Clüver 2002: 165). 


\section{med stjärnornas väldiga vo voly mma ssor buk tan de un der si na hu vu den hu vu den hu vu den hu vu den}

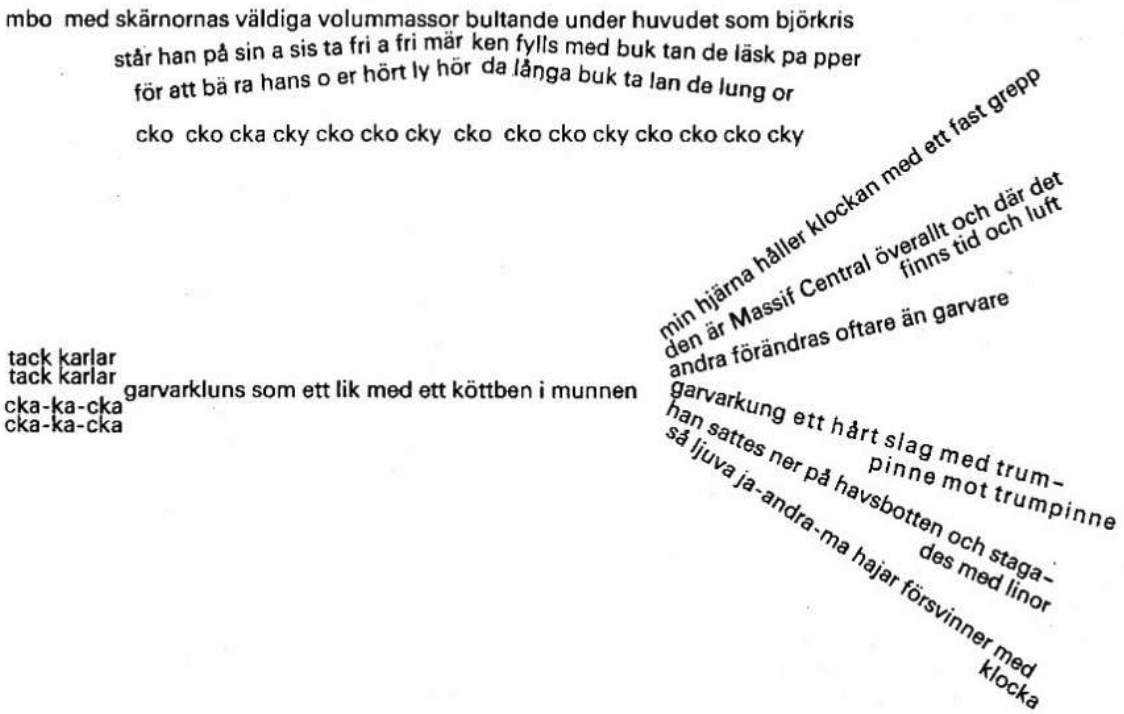

Figure 1. "Det stora och det lilla" (Fahlström 1966: 27)

What Fahlström was after was not a message, constructed as an interplay of the words' meanings and their visual form, which otherwise often highlighted an iconic relation between them. His aim was to abolish language rules for good and establish new ones, taking modern music as paradigm with its serial procedures, punctualism (socalled point music) and chance operations. He seems to have found pure material, devoid of conventional meanings, in music - the more so that experimental music of that time abolished all classic-romantic conventions that had established certain musical codes and could be semantically interpreted. To put it in another way, his intention was to explore the language as a medium and especially its overlooked aspect - namely, materiality. Materiality became the privileged quality in his poetics and a source for new, unforeseen energy of language, freed from its former functions and implications.

Having adopted the ideas from his manifesto in written or - more accurately speaking - printed poetry, Fahlström went on to exploit the oral potential of language signs. While carrying out experiments in a broadcast studio, he invented radio poetry based on recorded and electronically manipulated language sounds. In the meantime, his written poems were employed as verbal material for diverse live 
actions which gave raise to the genre of happening. Fahlström's artistic endeavours illustrate his vital interest in the possibilities of media. He did not consider language as $\boldsymbol{a}$ medium but explored different channels of its mediation, which, together with the material signs, constitute media: print (to be looked at); orality (to be perceived aurally but even with other senses, depending on the situation); technologically mediated sound, that is, according Walter J. Ong, secondary orality (1992: 183); and last but not least, performative aspects of language involved in stage actions.

Concrete poetry in Sweden did not follow the genres established by the early avant-garde - visual poetry and sound poetry. The poems were often labeled as visual sound poems (in Swedish bild-ljuddikter), the fact stressing that their medial shape could be varying. Bengt-Emil Johnson was another representative of the Swedish neo-avant-garde who put into effect Fahlström's artistic ideas. Let us have a closer look at some of Johnson's pieces of concrete poetry from the $1960^{\mathrm{s}}$ which expose his struggle to explore the potential of media as well as of language treated as "concrete material". He started with typed poetry (see Fig. 2) in which the language signs are detached, dissociated and spread all over the page, creating irregular patterns of varying density of signs. The arrangement undermines the principles of linearity, unidirectionality, readability and comprehensibility. This fact proves that applying semiotic analysis would be rather pointless here.

However, there is a hint that sheds light on the desired meaning of the poem: namely, its title, "Tribute to John Cage". Now the strategy of the poem becomes apparent: namely, a parallel between the fragmentation of language signs and the extended definition of music regarded by Cage as "the entire field of sound" (1961: 4), "a total-sound space" (1961: 9) and "the activity of sounds" (1961: 10) which are "events in the field of possibilities" (1961: 28). ${ }^{4}$

${ }^{4}$ Along with Fahlström, Johnson was very much involved in contemporary music and was fascinated by Cage's experiments. According to Erika Fischer-Lichte, Cage would expose performative aspects of music in his "events" and "pieces" (2004: 24). 


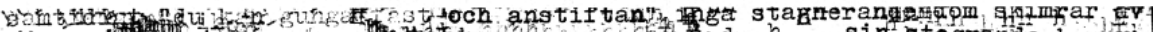

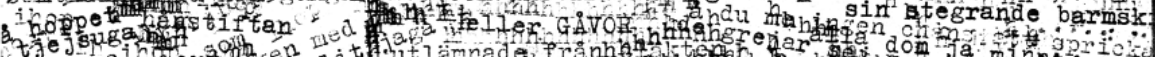

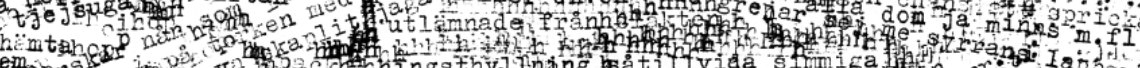

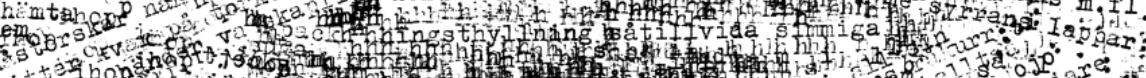

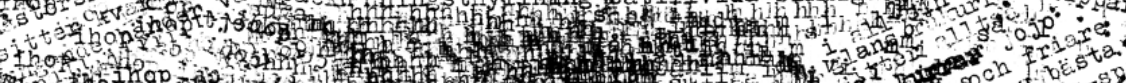

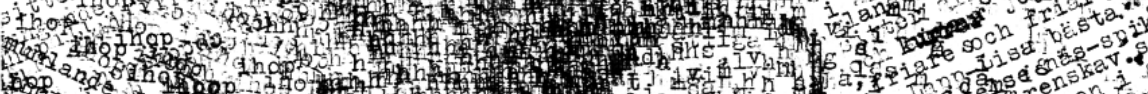

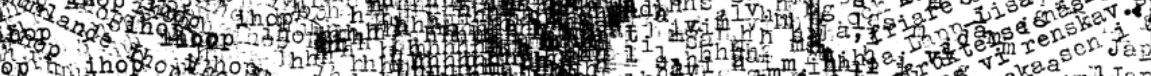
Qnopor

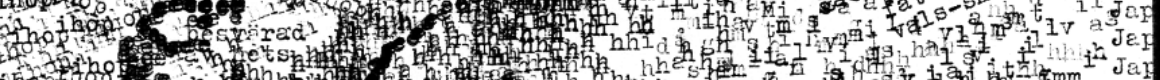

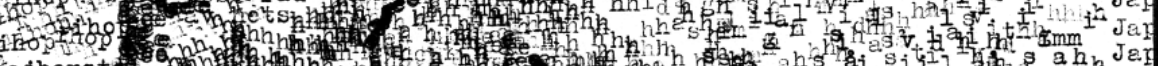

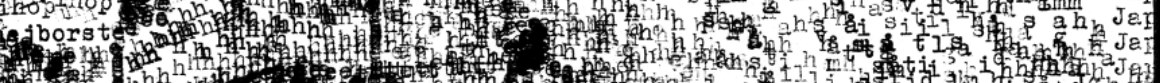
1.

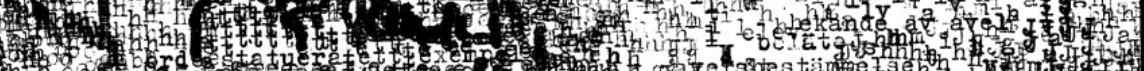

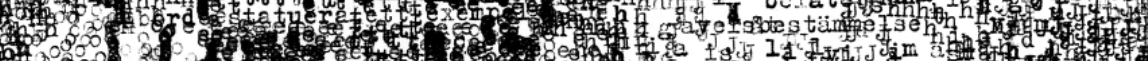

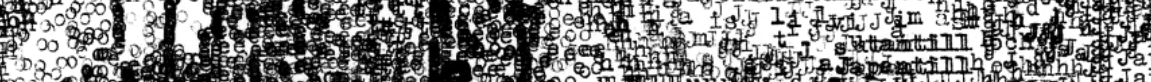

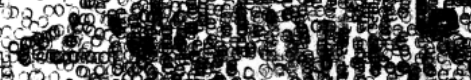

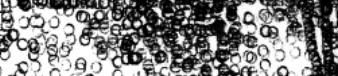

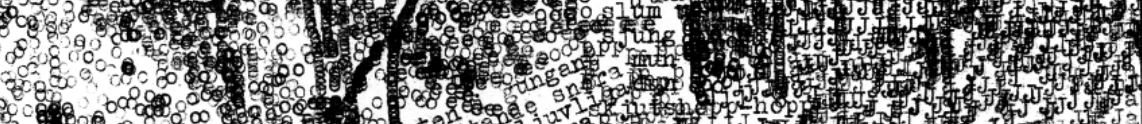

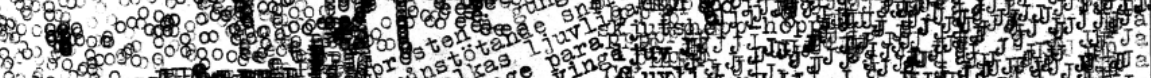

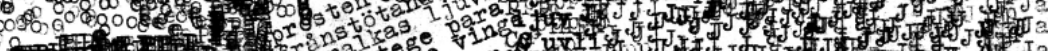

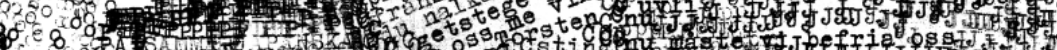
20 r Tin

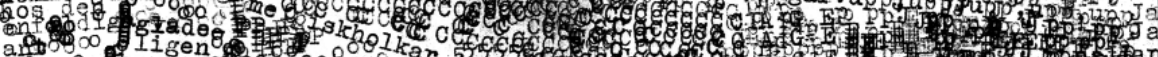

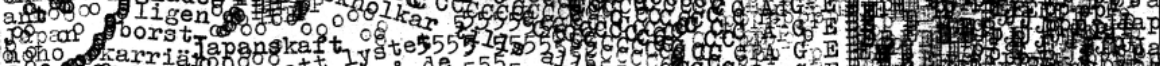

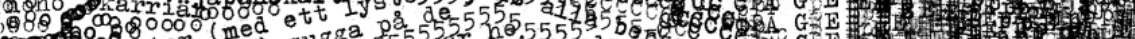
0000 ( tistry

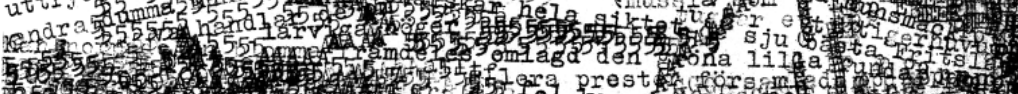

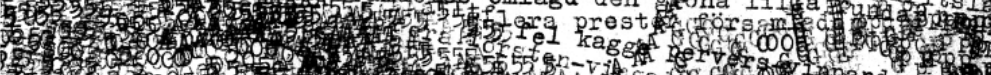

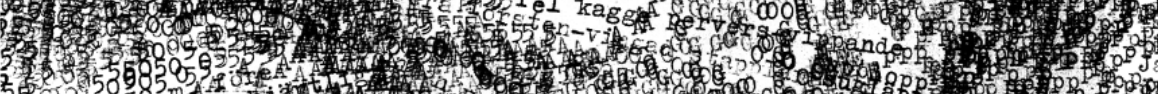

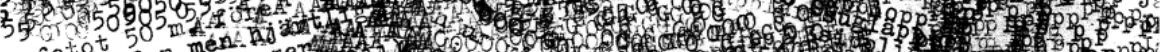

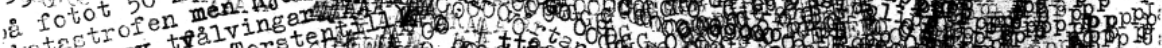

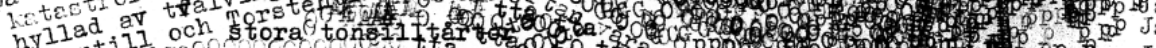

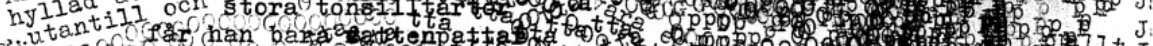

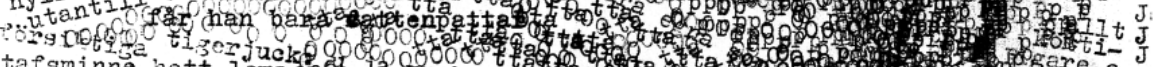

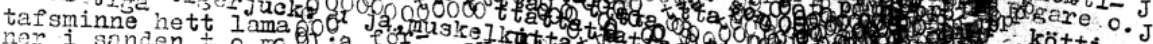
nor i senden t.

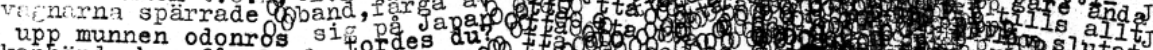

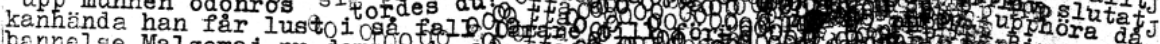

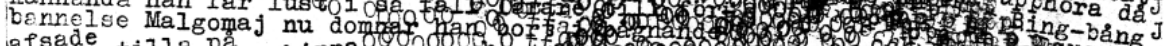

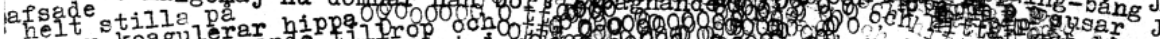
den nu kongu Japnande

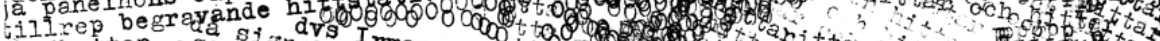

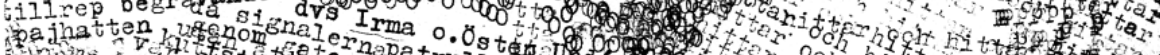

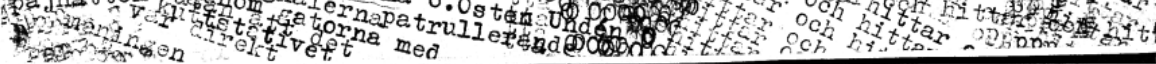

Figure 2. "Hyllning till John Cage" (Johnson 1964a) 
The poem is not meant to be read, nor is it to be taken in as an abstract visual composition. Its meaning emerges from, on the one hand, attempts to decipher the signs by way of trying various strategies and, on the other, to realize that no single strategy makes the text comprehensive. In fact, some coherent sequences of signs can be distinguished here: for instance, the name C A G E can be found among the overlapping letters in the middle of the composition. However, most of them lack the context and continuity which would make them meaningful. Hence, they remain separate fragments, like the material elements in a collage, and with their ontological duality of the primary materiality and semiotic function in the new context (Perloff 1986: 49). The principle of collage, underlying many concrete poems, makes us aware of materiality of signs before they gain their sign-status.

What I find in compositions like this is, first and foremost, the artistic examination of and reflection on the written medium. Experimental treatment of language signs, which violates the conventional rules of their usage, exposes their materiality and, thus, the medium itself along with the conditions of its mediation. I would say that such texts illustrate Marshall MacLuhan's well-known dictum, "the medium is the message" (2004:39). The printed medium, once it ceases to be transparent, constitutes the message about its complexity and latent mediating power.

Another vital aspect of Swedish concrete poetry is its potentially varying medial shape with many hints about oral or stage performance, confirming the thesis about artists' concern about media as crucial for the art of that time. Johnson's collection of concrete poems Gubbdrunkning does not show such typographic variety as his earlier typed poems. However, their typographic shape was, to some extent, the result of a compromise, a fact the author mentioned in the commentary to the book: "This book contains a selection of poems from the cycle 'Gubbdrunkning' (a shortened version). Due to the technical obstacles, my previous ideas about the typographic shape could not be realized" (Johnson 1965: 5).

As a matter of fact, some poems had been published before in the periodical Ord och Bild (1963-64) in a graphically more differentiated form and thus inviting to another strategy of reading. Let us have a look at typographic modifications in both texts (see Fig. 3 and 4).

The comparison between both images of the page confirms the book version (Fig. 4) was simplified compared to Figure 3, where the variety of font types and sizes, along with blank spaces, calls to mind the tradition of Futurist collage with its characteristics of newspaper and affiche typography. Both versions are based on nearly the same verbal material, but Figure 4 contains more performative hints which are rare in Figure 3. 
"POLISKAMERA"

(gong-gelé)

$\begin{array}{ll}\text { dit kan han } & \begin{array}{l}\text { inte komma } \\ \text { inte lăngre smålänning }\end{array} \\ \text { de vågar han } & \begin{array}{l}\text { inte } \\ \text { inte }\end{array}\end{array}$

lăngsamt:

ssjukdom...,

ifall vi kunde klämma at honom,

"s-j-u-k-d-o-m"

PX̃LMŐsa

han sitter ju på bänken fetknoppar, han badar ju, han e ju förskräckt hörrudu.

koloniträdgård med sjöfaglar:

klotter, hovtänger, medaljongerna fr. höger t. vänster d.v.s. shästlasss

somkoppling?

\section{FRUKTUPPVAKNARE}

sätt på honom grimman hörrudu, vi ska förhöra honom vi ska förhöra honom

sätt på honom

(väderkvarnar: han tycks pulsa, åberopa)

\section{$\mathbf{j} \mathbf{j} \mathbf{j} \mathbf{j} \mathbf{j} \mathbf{j} \mathbf{j} \mathbf{j} \mathbf{j} \mathbf{j} \mathbf{j} \mathbf{j} \mathbf{j} \mathbf{j} \mathbf{j} \mathbf{j} \mathbf{j} \mathbf{j}$}

4 ggr. varje da.

de e va han sajjer,

KRXK, GE ER!

Skiftgång i vissling, poliskamera.

Anländande: dala in så långsamt han nalkas, vaknare.

98 hä, tjallare: $\mathbf{R} \boldsymbol{A} T T V I S A$

RX̃TTVISA skvaltalare under pseudonym

RÄTTVISA »äh, de va vel inte så farlit,

RXTTVISA de kan va till sen hörrudus skimrande av stjärtfjädrar

släpa-vackla

utspridda

upprepning i provkök sdurkdrivens

\Underverk

valfria $\mathrm{i}$ rymden $\mathrm{i}$ himlen: fiskvatten

badvatten

sköljyatten

dricksvatten

tvättvatten

sjövatten

saltvatten

smältvatten

mineralvatten

bäckvatten strofforboto, strofforboto, stroffor

inom förtöjningsområdet frötöjning $\mathbf{M R A}$

hä, örtgök, äh bossen för skärarna, allt ehsammare, tunnare,

Figure 3. Johnson 1964b: 252 
(långsamt, utdraget, ganska svagt: "sjuk-dom ...

sjuuuuuuuk-doooooooom..."

etc.)

ifall vi kunde klämma åt honom (pälsmössa)

\section{FRUKTUPPVAKNARE.}

jijijijijijijijijj.

4 ggr. varje da de e va han säjer,

KRÄK, GE ER!

sätt på honom grimman hörrudu, vi ska förhöra honom!

vi ska förhöra honom

sätt på honom

4 ggr. varje da -

(väderkvarnar: han tycks pulsa, åberopa.)

hä, tjallare: RÄTTVISA

RÄTTVISA

RÄTTVISA

RÄTTVISA

under pseudonym: "äh, de va vel inte så farlit".

"äh, de kan va till sen, hörrudu".

m.fl. - alla skimrande av stjärtfjädrar.

upprepning $\mathrm{i}$ provkök:

I. Durkdriven.

2. "Underverk".

Inom förtöjningsområdet,

valfria i rymden $\mathrm{i}$ himlen: fiskvatten

badvatten

sköljvatten

än $d u d a ̊ a, v a ?$

tvättvatten

$d u d a \mathfrak{a}, v a, v a, d u$ ?

$d u, v a, d u, d u, v a, d u, v a, v a$ ?

$v a, d u, v a, v a, d u, v a, v a, v a, d u, v a$ ?

dricksvatten

sjövatten

saltvatten

smältvatten

(tydligt: "gång på gång,

mineralvatten

eftersom förhållandet

bäckvatten

mellan de olika luc-

korna - gluggarna -

förskjuts") 
It should be noted that the poems from Gubbdrunkning were performed on some occasions, and one of the performances was recorded and released as a single included with the book. Hence, an assumption can be made: namely, that the book version had been influenced by the performances towards a more acoustic-oriented concept, which had to be suggested by means other than visual artifice, as its possibilities were technologically restrained. The new solutions involve materialization of the voice, whereas Figure 3 is arranged according to visual syntax.

Generally, Figure 3 makes the impression of co-existing freestanding fragments spread all over the page, whereas Figure 4 seems more homogenous, due to the blocks being placed closer to one another, with less font variety and a stronger suggestion towards linearity. The means of treating language as "concrete material" are also different in both and related to the overall idea. Let me demonstrate this with a short example:

I (from Ord och Bild - see Fig. 3)

långsamt:

»sjukdom...»

"s-j-u-k-d-o-m"

[slowly: / »illness...» / "i-l-l-n-e-s-s"]

II (from the collection Gubbdrunkning - see Fig. 4)

(långsamt, utdraget, ganska svagt: "sjuk-dom... sjuuuuuuuk-doooooooom..."

etc.)

[(slowly, long-drawn-out, rather quietly: “illness.../ iiiiiiil-neeeeeeess..." / etc.)].

In the first example, the word "långsamt" [slowly] can be understood as a performative suggestion in the light of the quotation marks followed. The first instance of "sjukdom" [illness] conveys the lexical meaning; the sign is almost transparent with some suggestion of a pause marked by suspension points. Yet, the image of the word has been modified visually in the repetition. As a result of "radical artifice" (a term coined by Perloff in Radical Artifice), the length of the word concerned has been materialized by way of graphic means in the medium of print (spelling marked by hyphens). However, its atomizing does not match the rules of oral articulation, as it transforms the arbitrary language sign with its implied sound into a picture of the word. The performative instruction "långsamt" [slowly] is being realized as 'long' in the spatial sense, which, in turn, according to the strategy of the metaphor, is to be perceived as 'long' in the temporal sense: that is, uttered slowly, for a longer time. 
It is only the second version that implies oral aspects of the word as it conveys the manner of its articulation with graphic means according to more specified instructions in the text: "långsamt, utdraget, ganska svagt" [slowly, long-drawn-out, rather quietly]. Note well the parenthesis which indicates performance instruction. This time, the artifice matches the oral performance: first, by segmenting the word into syllables; then, by extending the vowels in accordance to its instruction (long-drawn-out).

As I have mentioned before, the text was performed in public and recorded. According to a description of the event, four readers were standing on ladders in the audience and performing the text - in sequence or simultaneously, using microphones and electronic manipulation of voices, especially reverberant effects (echo). However, the recorded text does not match the printed text in either version but it makes use of the verbal material found in both. It is a kind of collage of voices, which makes use of spatial effects: dynamics, echo, simultaneity, and rhythmic and phonetic organization stressing the oral aspects of language.

While the notion of collage in print is highly metaphorical (Perloff 1986: 72), suggested by typography, it becomes explicit in performance, as simultaneity and the overlapping of voices, together with their various locations, create the perception of a spatial arrangement. The methods of cut-up and montage of arbitrarily chosen, real, sound material are the same as those used in concrete music and aleatorism, and the result of applying them is a new sonic reality: heterogenic and polyphonic, but - contrary to reality - remaining constructed. Moreover, it could be constructed each time anew, with new relationships between the entities. Consequently, the symbolic space of a page became a real setting, whereas visual language modifications became events immersed in reality. Therefore, previously thought of as limited by time, this art has exposed the space and the body of a performer as well as the transience and the moment of the event, thanks to its performative effects.

These analyses assert that concrete poetry in its Swedish appearance of the so-called dirty concrete was conceived not so much as the conceptual integration of text and image in a constellation, governed by visual and verbal semiotic codes, but as an experimental examination of the media of print, voice, recording and performance, which exposed the materiality of signs mediated by different channels. Materiality became the central feature, overshadowing the verbal content and making it, to a great extent, irrelevant. At the same time, an aesthetics of the performative appeared as a phenomenon of particular importance, which led to the socalled performative turn (Fischer-Lichte 2004: 22). 
Among the fundamental indicators of the aesthetics of the performative is a physical closeness of performers and audience, which invites feedback (Fischer-Lichte 2004: 49); and materiality which emerges as a result of an activity within a performative space. A work of art is not an artifact but an event focusing on the present, presence and one-time effect (Fischer-Lichte 2004: 55-56). The aim of performative art is thus not to generate and convey certain meanings but to create phenomena to be received as they are (Fischer-Lichte 2004: 242). An event is defined through its materiality and, therefore, is self-referential (which means that the sign and the meaning are identical). It evokes, in a spectator, a luminal state: a sense of being somewhere between the mode of representation and presentation, and between experience and understanding.

To sum up, performative art aims at moving the recipient and not establishing certain meanings. In such cases, the semiotic perspective seems not to be able to embrace all aspects of signs and sign-making. Thus, it calls for an extension by media-related theories that involve other circumstances as to signs beyond just their significance. Many phenomena in contemporary art do not make use of the mode of representation but, rather, of the mode of presentation, for which it is experience - and not understanding - that is of central importance.

\section{References}

Arvidson, Jens, et al. (eds.) (2007a). Changing Borders: Contemporary Positions in Intermediality. Lund: Intermedia Studies Press.

Arvidson, Jens, et al. (eds.) (2007b). "Editor's Foreword". In: Changing Borders: Contemporary Positions in Intermediality. Ed. Jens Arvidson et al. (13-16). Lund: Intermedia Studies Press.

Bal, Mieke and Bryan Gonzales (eds.) (1997). The Practice of Cultural Analysis: Exposing Interdisciplinary Interpretation. Stanford, Calif.: Stanford University Press.

Cage, John (1961). Silence: Lectures and Writings. Middletown: Wesleyan University Press.

Clüver, Claus (1989). “On Intersemiotic Transposition”. Poetics Today 10 (1): 55-90.

Clüver, Claus (2002). "Concrete Sound Poetry: Between Poetry and Music". In: Cultural Functions of Intermedial Exploration. Eds. Erik Hedling and UllaBritta Lagerroth. (163-178). Amsterdam: Rodopi. 
Clüver, Claus (2007). "Intermediality and Interarts Studies". Changing Borders: Contemporary Positions in Intermediality. Eds. Jens Arvidson et al. (19-37). Lund: Intermedia Studies Press.

Culler, Jonathan (1997). Literary Theory. Oxford: Oxford University Press.

Elleström, Lars (ed.) (2010a). Media Borders, Multimodality and Intermediality. Basingstoke: Palgrave Macmillan.

Elleström, Lars (ed.) (2010b). "The Modalities of Media: A Model for Understanding Intermedial Relations". In: Media Borders, Multimodality and Intermediality. Ed. Lars Elleström. (11-46). Basingstoke: Palgrave Macmillan. Fahlström, Öyvind (1966). Bord. Dikter 1952-1955. Stockholm: Bonnier.

Fahlström, Öyvind (1968). "Hätila ragulpr på fåtskliaben. Manifesto för Concrete Poetry (1953)". Trans. K. Loevgren and Mary Ellen Solt. In: Concrete Poetry: A World View. Ed. Mary Ellen Solt. (74-78). Bloomington: Indiana University Press,.

Fischer-Lichte, Erika (2004). Ästhetik des Performativen. Frankfurt am Main: Suhrkamp.

Germano, William P. (1997). “Why Interdisciplinarity Isn't Enough?" In: The Practice of Cultural Analysis: Exposing Interdisciplinary Interpretation. Eds. Mieke Bal and Bryan Gonzales. (327-334). Stanford, Calif.: Stanford University Press.

Johnson, Bengt Emil (1963). Hyllningarna. Stockholm: Bonnier.

Johnson, Bengt Emil (1964a). Essäer om Bror Barsk och andra dikter. Stockholm: Bonnier.

Johnson, Bengt Emil (1964b). "Gubbdrunkning, fyrfota". Ord och Bild 3: 252-253. Johnson, Bengt Emil (1965). Gubbdrunkning. Stockholm: Bonnier.

Kranz, Gisbert (1981). Das Bildgedicht. I. Theorie. Köln: Böhlan.

Lund, Hans (2002). "Medier i samspel". Intermedialitet: Ord, bild och ton i samspel. Ed. Hans Lund. (9-22). Lund: Studentlitteratur.

McLuhan, Marshall (2004). Zrozumieć media: Przedłużenia człowieka. Introd. Lewis H. Lapham. Trans. Natalia Szczucka. Warszawa: Wydawnictwa NaukowoTechniczne.

Mitchell, William John Thomas (1994). Picture Theory: Essays on Verbal and Visual Representation. Chicago: University of Chicago Press.

Olsson, Jesper (2005). Alfabetets användning: Konkret poesi och poetisk artefaktion i svenskt 1960-tal. Munkedal: OEI Editör.

Ong, Walter J. (1992). Oralność i piśmienność: Słowo poddane technologii. Trans. Józef Japola. Lublin: Redakcja Wydawnictw KUL.

Perloff, Marjorie (1986). The Futurist Moment: Avant-Garde, Avant Guerre, and the Language of Rupture. Chicago: University of Chicago Press.

Perloff, Marjorie (1991). Radical Artifice: Writing Poetry in the Age of Media. Chicago: University of Chicago Press. 